Check for updates

Cite this: J. Mater. Chem. A, 2018, 6, 9099

Received 25th January 2018

Accepted 23rd April 2018

DOI: $10.1039 / c 8 t a 00822 a$

rsc.li/materials-a

\title{
Complex hydrides as thermal energy storage materials: characterisation and thermal decomposition of $\mathrm{Na}_{2} \mathrm{Mg}_{2} \mathrm{NiH}_{6} \dagger$
}

\begin{abstract}
Terry D. Humphries, (D) *ab Drew A. Sheppard, ${ }^{a}$ Guanqiao Li, ${ }^{b}$ Matthew R. Rowles, (D) a Mark Paskevicius, (D) Motoaki Matsuo, ${ }^{\text {cd }}$ Kondo-Francois Aguey-Zinsou, (D) M. Veronica Sofianos, (D) ${ }^{\text {a }}$ Shin-ichi Orimo ${ }^{\text {bd }}$ and Craig E. Buckley (iD)

Complex transition metal hydrides have been identified as being materials for multi-functional applications holding potential as thermal energy storage materials, hydrogen storage materials and optical sensors. $\mathrm{Na}_{2} \mathrm{Mg}_{2} \mathrm{NiH}_{6}\left(2 \mathrm{Na}^{+} \cdot 2 \mathrm{Mg}^{2+} \cdot 2 \mathrm{H}^{-} \cdot\left[\mathrm{NiH}_{4}\right]^{4-}\right)$ is one such material. In this study, the decomposition pathway and thermodynamics have been explored for the first time, revealing that at $225{ }^{\circ} \mathrm{C}$, hydrogen desorption commences with two major decomposition steps, with maximum $\mathrm{H}_{2}$ desorption rates at 278 and $350{ }^{\circ} \mathrm{C}$ as measured by differential scanning calorimetry. The first step of decomposition results in the formation of $\mathrm{Mg}_{2} \mathrm{NiH}_{x}(x<0.3)$ and $\mathrm{NaH}$, before these compounds decompose into $\mathrm{Mg}_{2} \mathrm{Ni}$ and $\mathrm{Na}$, respectively. $\mathrm{PCl}$ analysis of $\mathrm{Na}_{2} \mathrm{Mg}_{2} \mathrm{NiH}_{6}$ has determined the thermodynamics of decomposition for the first step to have a $\Delta H_{\text {des }}$ and $\Delta S_{\text {des }}$ of $83 \mathrm{~kJ} \mathrm{~mol}^{-1} \mathrm{H}_{2}$ and $140 \mathrm{~J} \mathrm{~K}^{-1} \mathrm{~mol}^{-1} \mathrm{H}_{2}$, respectively. Hydrogen cycling of the first step has been achieved for 10 cycles without any significant reduction in hydrogen capacity, with complete hydrogen desorption within $20 \mathrm{~min}$ at $395^{\circ} \mathrm{C}$. Despite the relatively high cost of $\mathrm{Ni}$, the ability to effectively store hydrogen reversibly at operational temperatures of $318-568{ }^{\circ} \mathrm{C}$ should allow this material to be considered as a thermal energy storage material.
\end{abstract}

\section{Introduction}

Recent years have seen a resurgence of interest into the synthesis and characterisation of complex metal hydrides ${ }^{\mathbf{1 - 3}}$ and complex transition metal hydrides (CTMH) ${ }^{4-6}$ Their thermal stability and hydrogen storage capacity have made this class of materials applicable for implementation as hydrogen storage materials, thermal energy storage (TES) materials ${ }^{7-9}$ and possibly as neutron moderators or nuclear fuel components in nuclear reactors. ${ }^{10}$ Furthermore, the rich and diverse chemistry made possible by the variety of cations (i.e. alkali, alkali-earth and rare-earth metals) $)^{\mathbf{4 , 1 1 , 1 2}}$ able to stabilise the transition metal hydride anion may prove useful in the development of multifunctional materials.

\footnotetext{
${ }^{a}$ Department of Physics and Astronomy, Fuels and Energy Technology Institute, Curtin University, GPO Box U1987, Perth,WA 6845, Australia.E-mail: terry_humphries81@ hotmail.com

${ }^{b}$ WPI-Advanced Institute for Materials Research, Tohoku University, Sendai 980-8577, Japan

${ }^{c}$ School of Science and Technology, Kwansei Gakuin University, Sanda 669-1337, Japan ${ }^{d}$ Institute for Materials Research, Tohoku University, Sendai 980-8577, Japan

${ }^{e}$ Merlin Group, School of Chemical Engineering, The University of New South Wales, Sydney, NSW 2052, Australia

$\dagger$ Electronic supplementary information (ESI) available: Quantitative analysis of $i n$ situ SR-XRD data; DSC-TPD-MS data; ex situ XRD data; absorption PCI data. See DOI: $10.1039 / \mathrm{c} 8 \mathrm{ta} 00822 \mathrm{a}$
}

One of the first CTMHs to be characterised was $\mathrm{Mg}_{2} \mathrm{NiH}_{4}$, in 1968. ${ }^{13}$ This material was reported to reversibly absorb and desorb hydrogen into the alloy of $\mathrm{Mg}_{2} \mathrm{Ni}$ with an enthalpy and entropy of desorption $\left(\Delta H_{\mathrm{des}}\right)$ of $64 \mathrm{~kJ} \mathrm{~mol}^{-1} \mathrm{H}_{2}$ and $\left(\Delta S_{\mathrm{des}}\right)$ of $122 \mathrm{~J} \mathrm{~K}^{-1} \mathrm{~mol}^{-1} \mathrm{H}_{2}$ (eqn (1)). In fact, upon decomposition, $\mathrm{Mg}_{2} \mathrm{NiH}_{4}$ proceeds through a $\mathrm{Mg}_{2} \mathrm{NiH}_{x}(x<0.3)$ phase as hydrogen is also dissolved in the $\mathrm{Mg}_{2} \mathrm{Ni}$ lattice.

$$
\mathrm{Mg}_{2} \mathrm{NiH}_{4} \rightleftarrows \mathrm{Mg}_{2} \mathrm{NiH}_{0.3}+1.85 \mathrm{H}_{2}\left(3.35 \mathrm{wt} \% \mathrm{H}_{2}\right)
$$

The initial study of $\mathrm{Mg}_{2} \mathrm{NiH}_{4}$ has fuelled a prolific interest in CTMHs and has led to the substitution of an array of metal centres for $\mathrm{Ni}$ in the complex anion (i.e. $\left[\mathrm{NiH}_{4}\right]^{4-}$ ) with many examples found in the literature: $\left[\mathrm{FeH}_{6}\right]^{4-},\left[\mathrm{CoH}_{5}\right]^{4-},\left[\mathrm{RuH}_{6}\right]^{4-}$, $\left[\mathrm{OsH}_{6}\right]^{4-},\left[\mathrm{IrH}_{5}\right]^{4-}$ and $\left[\mathrm{PdH}_{4}\right]^{4-}$.4,11,12,14,15 These materials have been extensively characterised, with several crystal structures determined using both neutron and X-ray diffraction (XRD). In addition, their thermodynamics have been determined by pressure-composition-isotherm (PCI) experiments, differential scanning calorimetry (DSC) and thermogravimetric analysis (TGA); while vibrational and nuclear magnetic resonance (NMR) spectroscopies have also been explored.

In the simplest compositions of these systems, all hydrogen atoms are bonded to the transition metal center $\mathrm{T}$ resulting in the chemical formula $\mathrm{M}_{m}{ }^{\delta+}\left[\mathrm{TH}_{n}\right]^{\delta-}(\mathrm{T}=3 \mathrm{~d}, 4 \mathrm{~d}, 5 \mathrm{~d}$ elements; $\mathrm{M}$ $=$ alkali, alkali-earth and rare-earth elements; $m, n=1,2$, 
$3, \ldots) .{ }^{16}$ The crystal structure of the archetypal compound, $\mathrm{Mg}_{2} \mathrm{NiH}_{4}$, consists of a $\mathrm{Ni}$ atom, coordinated by a distorted tetrahedron of four hydrogen atoms, forming the $\left[\mathrm{NiH}_{4}\right]^{4-}$ anion. ${ }^{17}$ This anion is thus stabilised within a distorted cubic array of $\mathrm{Mg}^{2+}$ cations. The room temperature polymorph of $\mathrm{Mg}_{2} \mathrm{NiH}_{4}$ resides in the monoclinic space group $C 2 / c$ with $a=$ 14.343(5) $\mathrm{A}, b=6.4038(10) \AA, c=6.4830(13), \AA$ and has an average Ni-D bond distance of 1.53(2) A. A transformation to a high temperature polymorph occurs in the range of 210$245{ }^{\circ} \mathrm{C},{ }^{18}$ and has been determined to crystallise in a pseudo$\mathrm{CaF}_{2}$-type structure with $a=6.490 \AA$ A. These polymorphs have undergone a plethora of studies to understand their true physical properties, which have recently been detailed in a review article. ${ }^{4}$

To date there are eight known compounds incorporating the $\left[\mathrm{NiH}_{4}\right]^{4-}$ complex anion including $\mathrm{MMgNiH}_{4}(\mathrm{M}=\mathrm{Mg}, \mathrm{Sr}, \mathrm{Eu}$, $\mathrm{Ca}, \mathrm{Yb}),{ }^{4,17,19,20} \mathrm{Na}_{2} \mathrm{Mg}_{2} \mathrm{NiH}_{6},{ }^{21,22} \mathrm{LaMg}_{2} \mathrm{NiH}_{7}$ (ref. 23 and 24) and $\mathrm{La}_{2} \mathrm{MgNi}_{2} \mathrm{H}_{8} \cdot{ }^{25} \mathrm{MMgNiH}_{4}(\mathrm{M}=\mathrm{Sr}, \mathrm{Eu}, \mathrm{Ca}, \mathrm{Yb})$ are isostructural, crystalising in the cubic space group $P 2{ }_{1} 3 .^{12,13}$ As observed with $\mathrm{Mg}_{2} \mathrm{NiH}_{4}$, the $\left[\mathrm{NiH}_{4}\right]^{4-}$ is coordinated by a distorted cube of two $\mathrm{M}^{2+}$ and two $\mathrm{Mg}^{2+}$ atoms. $\mathrm{LaMg}_{2} \mathrm{NiH}_{7}$ and $\mathrm{Na}_{2} \mathrm{Mg}_{2} \mathrm{NiH}_{6}$ represent a class of materials in which the $\left[\mathrm{NiH}_{4}\right]^{4-}$ is coordinated by an array of $\mathbf{M}(\mathbf{M}=\mathrm{La}, \mathrm{Na}, \mathrm{Mg})$ cations, but are seen as a link between 'interstitial' and 'complex' metal hydrides due to the inclusion of quasi-isolated $\mathrm{H}^{-} .21-24$

$\mathrm{Na}_{2} \mathrm{Mg}_{2} \mathrm{NiH}_{6}\left(2 \mathrm{Na}^{+} \cdot 2 \mathrm{Mg}^{2+} \cdot 2 \mathrm{H}^{-} \cdot\left[\mathrm{NiH}_{4}\right]^{4-}\right)$ was first synthesised in 2007, and the structure, elucidated from neutrondiffraction data, exists in the orthorhombic space group Pnma. $^{21}$ In 2009, the structure was revised using ab initio structure analysis, along with newly collected diffraction data. ${ }^{22}$ Although the space group, Pnma, was originally correct, the lattice parameters were revised to be $a=11.433(1) \AA, b=$ 8.4435(8) $\AA$, $c=5.4180(7) \AA$, along with an alteration in the description of the overall structure. As such, the $\left[\mathrm{NiH}_{4}\right]^{4-}$ is surrounded by two $\mathrm{Na}^{+}$and two $\mathrm{Mg}^{2+}$ ions (Fig. 1a), while the quasi-isolated $\mathrm{H}^{-}$ions are coordinated four-fold by $2 \mathrm{Mg}^{2+}$ and $2 \mathrm{Na}^{+}$ions (Fig. 1b). ${ }^{22}$ In the deuterated version of this compound, the average Ni-D distance is 1.61(2) $\AA$, which is significantly longer than that of $\mathrm{Mg}_{2} \mathrm{NiD}_{4}$, indicating the mutual contribution of both countercations on the $\left[\mathrm{NiD}_{4}\right]^{4-} \cdot{ }^{26}$ Overall, the structure of $\mathrm{Na}_{2} \mathrm{Mg}_{2} \mathrm{NiH}_{6}$ can be described as a stacking of $\left(\mathrm{NaMgH}_{2}\right)^{+}$and $\left(\mathrm{NaMgNiH}_{4}\right)^{-}$slabs (Fig. 1c). ${ }^{22}$
The synthesis of $\mathrm{Na}_{2} \mathrm{Mg}_{2} \mathrm{NiH}_{6}$ was previously achieved by first synthesising $\mathrm{Mg}_{2} \mathrm{NiH}_{4}$ from the hydrogenation of $\mathrm{Mg}_{2} \mathrm{Ni}$ at $200{ }^{\circ} \mathrm{C}^{22}$ The product was then mixed in a $1: 2$ ratio with $\mathrm{NaH}$ and ground to a fine powder in an agate mortar, compacted to pellets, put into a steel crucible, and sintered in an autoclave at $300-315{ }^{\circ} \mathrm{C}$ under 50 bar $\mathrm{H}_{2}$ for $24 \mathrm{~h}$.

The decomposition pathway of $\mathrm{Na}_{2} \mathrm{Mg}_{2} \mathrm{NiH}_{6}$ has not been elucidated and hence neither have the thermodynamics of decomposition. To date, only four $\left[\mathrm{NiD}_{4}\right]^{4-}$ complexes have been thermodynamically characterised: $\mathrm{Mg}_{2} \mathrm{NiH}_{4}, \mathrm{LaMg}_{2} \mathrm{NiH}_{7}$, $\mathrm{YbMgNiH}_{4}$ and $\mathrm{CaMgNiH}_{4}$, each with a $\Delta H_{\text {des }}$ of $64.4,94,111$ and $129 \mathrm{~kJ} \mathrm{~mol}^{-1} \mathrm{H}_{2}$, respectively (Table 1 ). ${ }^{13,19,20,23}$ It was originally understood that these values are not directly related to the electronegativity of the $\mathbf{M}$ atom, instead that the thermal stability is governed considerably by the $\Delta H_{\mathrm{f}}$ of the corresponding binary hydride (Table 1 ). ${ }^{20}$ Overall, the average electronegativity of the cation, $\chi_{\mathrm{a}}$, (Allred-Rochow scale) appears to have a stronger influence on the stability of the complex than the stability of the corresponding binary hydride. ${ }^{26}$ The average $\chi_{\mathrm{a}}$ of $\mathrm{Mg}_{2} \mathrm{NiH}_{4}, \mathrm{LaMg}_{2} \mathrm{NiH}_{7}, \mathrm{YbMgNiH}_{4}$ and $\mathrm{CaMgNiH}_{4}$ are 1.23, $1.18,1.15$ and 1.14 , which is inversely proportional to the $\Delta H_{\text {des }}$ of the complexes (i.e. $\mathrm{Mg}_{2} \mathrm{NiH}_{4}<\mathrm{LaMg}_{2} \mathrm{NiH}_{7}<\mathrm{YbMgNiH}_{4}<$ $\left.\mathrm{CaMgNiH}_{4}\right)$.

The decomposition pathway of $\mathrm{Na}_{2} \mathrm{Mg}_{2} \mathrm{NiH}_{6}$ is studied for the first time in this research. It is anticipated that $\mathrm{Na}_{2} \mathrm{Mg}_{2} \mathrm{NiH}_{6}$ will decompose in a two-stage process via the formation of a binary hydride $(\mathrm{NaH})$, as observed in other CTMHs (eqn (2) and (3))., ${ }^{\mathbf{4 1 3 , 1 9 , 2 0 , 2 3}}$ The decomposition pathway has been studied in detail using in situ synchrotron powder X-ray diffraction (SRXRD) and simultaneous DSC-TGA-MS (DSC-TGA-mass spectrometry) and the thermodynamics of the decomposition process have been determined by PCI measurements. The determination of the decomposition pathway and thermodynamic measurements will ultimately identify the feasibility of this material for technological applications. The synthesis method of $\mathrm{Na}_{2} \mathrm{Mg}_{2} \mathrm{NiH}_{6}$ has also been optimised allowing for facile manufacturing of this powder for future applications.

$$
\begin{aligned}
\mathrm{Na}_{2} \mathrm{Mg}_{2} \mathrm{NiH}_{6} \rightarrow & \mathrm{Mg}_{2} \mathrm{NiH}_{x}+2 \mathrm{NaH} \\
& +(2-x) \mathrm{H}_{2}\left(x<0.3,>2.15 \mathrm{wt}^{\%} \mathrm{H}_{2}\right)
\end{aligned}
$$

(a)

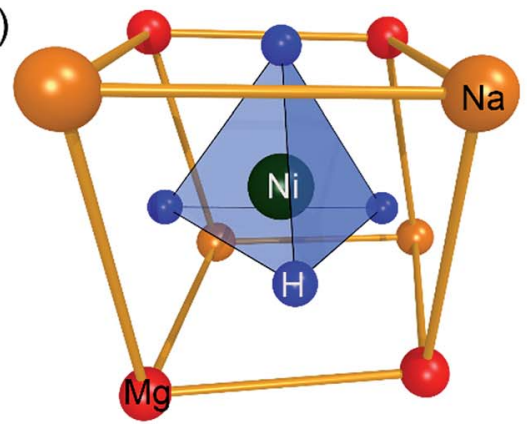

(b)

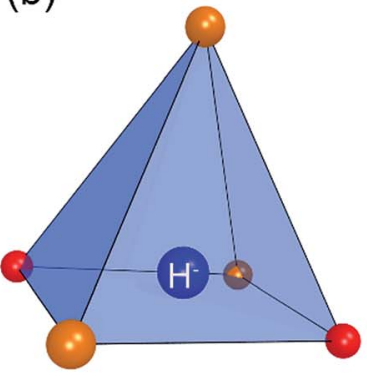

(c)

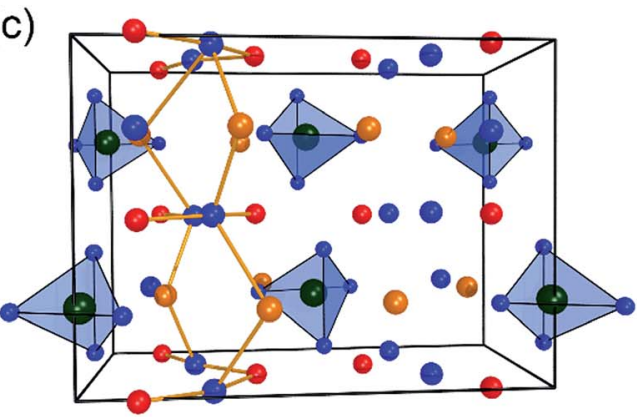

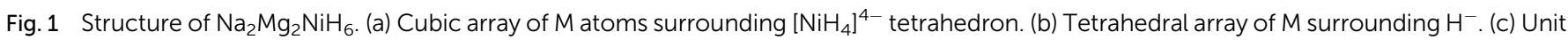
cell showing $\left(\mathrm{NaMgH}_{2}\right)^{+}$and $\left(\mathrm{NaMgNiH}_{4}\right)^{-}$slabs. $\mathrm{M}=\mathrm{Na}$, Mg. Green spheres represent $\mathrm{Ni}$; blue spheres represent $\mathrm{H}$; orange spheres represent $\mathrm{Na}$; red spheres represent $\mathrm{Mg}$. 
Table 1 Properties of $\left[\mathrm{NiH}_{4}\right]^{4-}$ complexes including average electronegativity $\left(\chi_{\mathrm{a}}\right)$ of $\mathrm{M}$ atom (Allred-Rochow scale), Ni-H bond distances (of their deuterides), $\Delta H$ of decomposition of the complex hydride and $\Delta H$ of formation of binary metal hydride

\begin{tabular}{|c|c|c|c|c|c|c|}
\hline & $\begin{array}{l}\text { Space } \\
\text { group }\end{array}$ & $\begin{array}{l}\text { Average } \\
\text { cation } \chi_{\mathrm{a}}\end{array}$ & Lattice parameter of deuteride $(a, \AA)$ & Average Ni-D bond distance $(\AA)$ & $\begin{array}{l}\Delta H_{\mathrm{des}} \\
\left(\mathrm{kJ} \mathrm{mol}^{-1} \mathrm{H}_{2}\right)\end{array}$ & $\begin{array}{l}\Delta H_{\mathrm{f}} \mathrm{MH}_{y}{ }^{c} \\
\left(\mathrm{~kJ} \mathrm{~mol}^{-1} \mathrm{H}_{2}\right)\end{array}$ \\
\hline $\mathrm{Mg}_{2} \mathrm{NiH}_{4}$ & $C 2 / c$ & 1.23 & 14.343 (ref. 17) & 1.53(2) (ref. 17) & 64.4 (ref. 13) & -74.1 (ref. 27 ) \\
\hline $\mathrm{YbMgNiH}_{4}$ & $P 2{ }_{1} 3$ & 1.15 & $6.7114(6)($ ref. 20) & $1.608(7)$ (ref. 20) & 111 (ref. 20) & -182 (ref. 29) \\
\hline $\mathrm{CaMgNiH}_{4}$ & $P 2{ }_{1} 3$ & 1.14 & $6.7301(4)$ (ref. 19) & $1.601(8)$ (ref. 19) & 129 (ref. 19) & -188 (ref. 29) \\
\hline $\mathrm{Na}_{2} \mathrm{Mg}_{2} \mathrm{NiH}_{6}$ & Pnma & 1.12 & 11.433(1) (ref. 22) & $1.61(2)($ ref. 22$)$ & - & -117 (ref. 30) \\
\hline $\mathrm{La}_{2} \mathrm{MgNi}_{2} \mathrm{H}_{8}$ & $P 22_{1} / c$ & 1.08 & $11.84482(11)$ (ref. 25) & $1.58^{b}$ (ref. 25) & - & -209 (ref. 28) \\
\hline
\end{tabular}

${ }^{a}$ Lattice parameter of hydride. ${ }^{b}$ Errors not provided. ${ }^{c} \mathrm{M}$ is La ${ }^{2+}, \mathrm{Yb}^{2+}, \mathrm{Ca}^{2+}, \mathrm{Na}^{+}, \mathrm{Sr}^{2+}$ for the corresponding compound except for $\mathrm{Mg}_{2} \mathrm{NiH}_{4}$ where $\mathrm{M}$ is $\mathrm{Mg} ; \mathrm{y}$ corresponds to the valence of $\mathrm{M}$.

$$
2 \mathrm{NaH} \rightarrow 2 \mathrm{Na}+\mathrm{H}_{2}\left(1.27 \mathrm{wt} \% \mathrm{H}_{2}\right)
$$

\section{Experimental}

All handling of chemicals and sealable milling canisters was undertaken in an argon-atmosphere Mbraun Unilab glovebox in order to minimise oxygen $\left(\mathrm{O}_{2}<1 \mathrm{ppm}\right)$ and water $\left(\mathrm{H}_{2} \mathrm{O}<1 \mathrm{ppm}\right)$ contamination. To synthesise $\mathrm{Na}_{2} \mathrm{Mg}_{2} \mathrm{NiH}_{6}$, two methods were employed. The majority of the material used in this study employed the two-step synthesis method which entailed the ball-milling of $\mathrm{NaH}$ (95\%, Sigma-Aldrich), $\mathrm{MgH}_{2}$ (hydrogen storage grade, Sigma-Aldrich) and Ni powder ( $>99.8 \%$, SigmaAldrich) in a stoichiometric ratio of $2: 2: 1$. Following milling, the samples were generally annealed under a $\mathrm{H}_{2}$ pressure of 50 bar at $315{ }^{\circ} \mathrm{C}$ for $20 \mathrm{~h}$. Ball milling was conducted inside an Across International Planetary Ball Mill (PQ-N04) employing tempered steel vials and balls in an Ar atmosphere. A ball-topowder mass ratio of $40: 1$ was employed, with a total milling time of $5 \mathrm{~h}$ (15 min milling and $5 \mathrm{~min}$ pause) at a speed of $450 \mathrm{rpm}$.

The four-step synthesis method, adapted from previous reports, ${ }^{22}$ involved the milling of $\mathrm{MgH}_{2}$ (hydrogen storage grade, Sigma Aldrich) and Ni powders at a molar ratio of $2: 1$ for $2 \mathrm{~h}$ at $400 \mathrm{rpm}$ (ball-to-powder ratio $40: 1$ ), under argon using a Fritsch Pulverisette 7 . The pelletised powder was then annealed at $300{ }^{\circ} \mathrm{C}$ for $20 \mathrm{~h}$ under $3 \mathrm{bar} \mathrm{H}_{2}$. The resultant brickred powder was then ball-milled with $\mathrm{NaH}$ ( $95 \%$, Sigma Aldrich) at a molar ratio of $1: 2$ for $20 \mathrm{~h}$ under argon with subsequent heat treatment of the pelletised powder at $300{ }^{\circ} \mathrm{C}$ for $20 \mathrm{~h}$ under $60 \mathrm{bar} \mathrm{H}_{2}$. The final product was as an olive-green powder.

Ex situ powder X-ray diffraction (XRD) was performed using a Bruker D8 Advance diffractometer $(\lambda=\mathrm{CuK} \alpha$ radiation) utilising XRD sample holders covered with a poly (methylmethacrylate) (PMMA) airtight dome to prevent oxygen/ moisture contamination during data collection. The PMMA airtight dome results in a broad hump in XRD patterns centred at $\sim 20^{\circ} 2 \theta$. Data was acquired over a $2 \theta$ range of $20-80^{\circ}$, with step size of $0.02^{\circ}$ and count time of $1 \mathrm{~s}$ per step. In situ synchrotron powder X-ray diffraction (SR-XRD) was performed at the Australian Synchrotron in Melbourne, Australia. ${ }^{31}$ The annealed powder was loaded in a borosilicate capillary (outer diameter $0.7 \mathrm{~mm}$, wall thickness $0.01 \mathrm{~mm}$ ) while inside a glove box, and mounted using a graphite ferrule to a sample holder constructed from Swagelok tube fittings. The sample holder was then connected to a $\mathrm{H}_{2}$ gas filling/vacuum manifold and the capillary heated with a hot air blower with a heating rate of $5{ }^{\circ} \mathrm{C} \min ^{-1}$ and under a 1 bar $\mathrm{H}_{2}$ atmosphere. One-dimensional SR-XRD patterns (monochromatic X-rays with $\lambda=0.824890(1)$ A) were continuously collected using a Mythen microstrip detector $^{32}$ with an exposure time of $27 \mathrm{~s}$. The capillary was continuously oscillated through $120^{\circ}$ during exposure to improve the powder averaging and ensure even heating. Diffraction patterns were quantitatively analysed with the Rietveld method ${ }^{33}$ using TOPAS (Bruker-AXS).

The hydrogen sorption properties were examined by measuring PCIs between 370 and $450{ }^{\circ} \mathrm{C}$ with a computer controlled Sieverts/volumetric apparatus previously described. ${ }^{27}$ The digital pressure transducer (Rosemount 3051S) has an accuracy of $0.15 \%$, whilst room temperature measurements were recorded using a 4-wire platinum resistance temperature detector (RTD). The sample temperature was monitored using a K-type thermocouple that was calibrated by the manufacturer to be accurate within $0.1{ }^{\circ} \mathrm{C}$ at $419{ }^{\circ} \mathrm{C}$. Above $\sim 420{ }^{\circ} \mathrm{C}$, the permeation of hydrogen directly through the walls of the stainless-steel sample cell becomes an issue and the measured hydrogen content at each PCI data point has to be corrected for this loss. A full explanation of the correction method has previously been described in detail. ${ }^{34}$ The cycling experiments were carried out using a High Energy PCTpro E\&E. The first decomposition was conducted by heating the sample to $315^{\circ} \mathrm{C}$ under 60 bar $\mathrm{H}_{2}$ before reducing the $\mathrm{H}_{2}$ pressure to 0.2 bar. The temperature was then increased to $395{ }^{\circ} \mathrm{C}$ at a rate of $10^{\circ} \mathrm{C} \mathrm{min}^{-1}$ to promote desorption. Subsequent absorption and desorption cycles were carried out as follows: after the first dehydrogenation, the $\mathrm{H}_{2}$ pressure and temperature were reduced to 0.2 bar and $315{ }^{\circ} \mathrm{C}$, respectively. The hydrogen pressure was then increased to 60 bar to initiate hydrogenation. The temperature was then increased to $395{ }^{\circ} \mathrm{C}$ at a rate of $10{ }^{\circ} \mathrm{C} \min ^{-1}$ before reducing the $\mathrm{H}_{2}$ pressure to 0.2 bar to initiate decomposition. This was repeated to achieve a total of 10 cycles before leaving the sample in the hydrogenated state. 
Furthermore, 30 cycles where completed with desorption being carried out under an initial back pressure of 0.7 bar $\mathrm{H}_{2}$ for $1 \mathrm{~h}$ and absorption being conducted under an initial pressure of 40 bar for $2 \mathrm{~h}$ at $395{ }^{\circ} \mathrm{C}$.

DSC-TGA-MS were conducted at $10{ }^{\circ} \mathrm{C} \mathrm{min}^{-1}$ under an argon flow of $20 \mathrm{~mL} \mathrm{~min}{ }^{-1}$ using a Mettler Toledo TGA/DSC 1 coupled with an Omnistar MS. Mass to charge ratios $(\mathrm{m} / \mathrm{e}-\mathrm{m}$ in atomic mass units and $e$ the electronic charge) ranging between 2 and 100 were followed up at a temperature of $400{ }^{\circ} \mathrm{C}$. The instrument was operated within an Ar filled glovebox to avoid contamination during sample handling. The temperature accuracy of this instrument is $\pm 0.2^{\circ} \mathrm{C}$, while the balance has an accuracy of $\pm 20 \mu \mathrm{g}$.

\section{Results and discussion}

\section{Thermal decomposition experiments}

SR-XRD (Fig. 2) of the two-step synthesised olive-green powder was analysed by Rietveld refinement and the lattice parameters were determined to be $a=11.4255(4) \AA, b=8.4413(3) \AA$, and $c=$ 5.4154(2) Å: in excellent agreement with $a=11.4297(3) \AA$, $b=$ $8.4430(2) \AA$ and $c=5.4197(1) \AA$ previously determined by neutron diffraction (space group Pnma). ${ }^{22}$ Further, quantitative analysis determined that the synthesised material consisted of $\mathrm{Na}_{2} \mathrm{Mg}_{2} \mathrm{NiH}_{6}$ (76.2(3) wt\%), $\mathrm{MgNi}_{2}$ (12.1(2) wt\%), $\mathrm{NaMgH}_{3}$ (7.3(1) wt\%) and $\mathrm{NaH}(4.4(1) \mathrm{wt} \%)$. This is also in close agreement with the four-step synthesis strategy imposed previously for $\mathrm{Na}_{2} \mathrm{Mg}_{2} \mathrm{NiH}_{6}$ (69 wt\%), $\mathrm{Mg}_{2} \mathrm{NiH}_{4}$ (4 wt\%), $\mathrm{NaMgH}_{3}$ (10 wt\%), $\mathrm{NaH}$ (3 wt\%), and $\mathrm{NaOH}(14$ wt $\%) .{ }^{22}$ Overall, the two-step method (eqn (4)) is highly efficient with regards to synthesis time and product purity compared to the previously reported four-step method (eqn (5) and (6)).

$$
2 \mathrm{NaH}+2 \mathrm{MgH}_{2}+\mathrm{Ni} \underset{(2) 315^{\circ} \mathrm{C}, 60 \mathrm{bar} \mathrm{H}_{2}}{\stackrel{(1) \mathrm{BM}, 450 \mathrm{rmm}, 5 \mathrm{~h}}{\longrightarrow}} \mathrm{Na}_{2} \mathrm{Mg}_{2} \mathrm{NiH}_{6}
$$

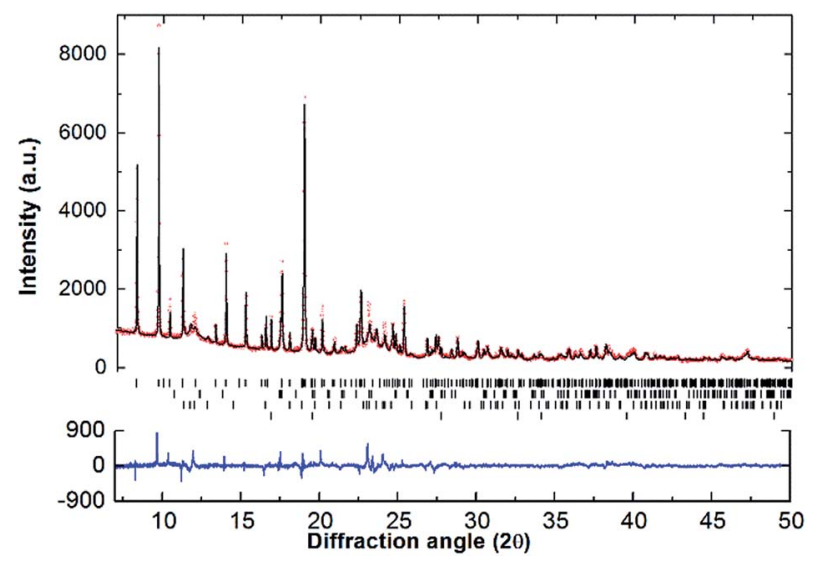

Fig. 2 Room temperature SR-XRD pattern and Rietveld refinement plot of $\mathrm{Na}_{2} \mathrm{Mg}_{2} \mathrm{NiH}_{6}$. Experimental data as red circles, calculated diffraction pattern as black line and the difference plot in blue. Tick marks show positions for: $\mathrm{Na}_{2} \mathrm{Mg}_{2} \mathrm{NiH}_{6}$ (76.2(3) wt\%), $\mathrm{NaMgH}_{3}$ (7.3(1) wt\%), $\mathrm{MgNi}_{2}$ (12.1(2) wt\%) and $\mathrm{NaH}$ (4.4(1) wt\%), top to bottom respectively. $\lambda=0.824890(1) \AA, T=27^{\circ} \mathrm{C}$.

$$
\begin{gathered}
2 \mathrm{MgH}_{2}+\mathrm{Ni} \underset{\text { (2) } 300^{\circ} \mathrm{C}, 3 \text { bar } \mathrm{H}_{2}}{\stackrel{(1) \mathrm{BM}, 400 \mathrm{rpm}, 2 \mathrm{~h}}{\longrightarrow}} \mathrm{Mg}_{2} \mathrm{NiH}_{4} \\
2 \mathrm{NaH}+\mathrm{Mg}_{2} \mathrm{NiH}_{4} \underset{(4) 300^{\circ} \mathrm{C}, 60 \mathrm{bar} \mathrm{H}_{2}}{\stackrel{(3) \mathrm{BM}, 400 \mathrm{rpm}, 5 \mathrm{~h}}{\longrightarrow}} \mathrm{Na}_{2} \mathrm{Mg}_{2} \mathrm{NiH}_{6}
\end{gathered}
$$

Apart from the report of the original synthesis ${ }^{21}$ of $\mathrm{Na}_{2} \mathrm{Mg}_{2}$ $\mathrm{NiH}_{6}$ and the subsequent structure determination by powder neutron diffraction, ${ }^{22}$ no further experimental studies have been published concerning this material. It is particularly interesting that the decomposition pathway of this compound has not been determined considering the attention its analogue, $\mathrm{Mg}_{2} \mathrm{NiH}_{4}$, has received as a hydrogen storage material. ${ }^{\mathbf{4}, \mathbf{1 3 , 3 5 - 4 3}}$ In this research, initial studies of the decomposition pathway for $\mathrm{Na}_{2} \mathrm{Mg}_{2} \mathrm{NiH}_{6}$ were carried out by in situ SR-XRD experiments. These experiments allow for the identification of all crystalline species that are present or evolve during decomposition, while simultaneously determining the temperatures at which these processes occur. Fig. 3 illustrates the in situ heating experiment, performed under 1 bar of $\mathrm{H}_{2}$ back pressure, in which the composition of all the crystalline phases were determined as a function of temperature. It is evident that $\mathrm{Na}_{2} \mathrm{Mg}_{2}$ $\mathrm{NiH}_{6}$ undergoes decomposition in a two- step process which begins at $\sim 280{ }^{\circ} \mathrm{C}$. As the intensity of the crystalline $\mathrm{Na}_{2} \mathrm{Mg}_{2}$ $\mathrm{NiH}_{6}$ phase declines, the quantity of the $\mathrm{MgNi}_{2}, \mathrm{NaH}$ and $\mathrm{NaMgH}_{3}$ phases begin to increase, while $\mathrm{Mg}_{2} \mathrm{Ni}$ is observed for the first time at $\sim 320{ }^{\circ} \mathrm{C}$. Above $340{ }^{\circ} \mathrm{C}$, transient $\mathrm{NaMgH}_{3}$ and $\mathrm{MgNi}_{2}$ begin to decrease while $\mathrm{Na}_{2} \mathrm{Mg}_{2} \mathrm{NiH}_{6}$ can no longer be observed. By $360{ }^{\circ} \mathrm{C}, \mathrm{NaMgH}_{3}$ has been totally consumed, whereas the other species, including $\mathrm{NaH}$ remain throughout the experiment (Fig. 3 and S1 $\dagger$ ). Interestingly, PCI analysis does not show an equilibrium plateau for $\mathrm{NaMgH}_{3}$, ex situ XRD diffraction does not exhibit Bragg peaks for $\mathrm{NaMgH}_{3}$, and DSCTGA-MS only shows a small shoulder (each shown below). Hence, we postulate that $\mathrm{NaMgH}_{3}$ is a transient intermediate in the reaction. The in situ XRD experiment was stopped at $\sim 410{ }^{\circ} \mathrm{C}$ and so the second stage of decomposition was not observed. It is anticipated that the $\mathrm{NaH}$ phase would leave $\mathrm{Na}$ metal upon decomposition.

$\mathrm{Mg}$ poor $\mathrm{MgNi}_{2}$ is formed in a large quantity during the in situ SR-XRD experiment. This is in contrast to ex situ XRD results (see below) and it is therefore concluded that $\mathrm{MgNi}_{2}$ is not normally part of the decomposition process but may merely be a by-product formed due to $\mathrm{Mg}$ loss. This may be attributed to the formation of amorphous/nanocrystalline $\mathrm{MgO}$, which would leave $\mathrm{Mg}_{2} \mathrm{Ni}$ unable to be formed stoichiometrically.

Upon closer inspection, it is apparent that while the decomposition of $\mathrm{Na}_{2} \mathrm{Mg}_{2} \mathrm{NiH}_{6}$ follows a two-step decomposition pathway, there are also some underlying processes occurring. At $\sim 100{ }^{\circ} \mathrm{C}$, a distinct expansion of the lattice parameters of $\mathrm{NaH}$ are observed from 4.8978 to $4.9094 \AA$, which is especially apparent for the peak at $2 \theta=16.8^{\circ}$. Coincidentally, an exothermic peak at $97{ }^{\circ} \mathrm{C}$ is also observed by DSC analysis without a concomitant mass loss detected by TGA (Fig. S2 $\dagger$ ). This process is associated with the dissolution of $\mathrm{NaOH}$ impurities into the $\mathrm{NaH}$ lattice. Studies have shown that as little as 


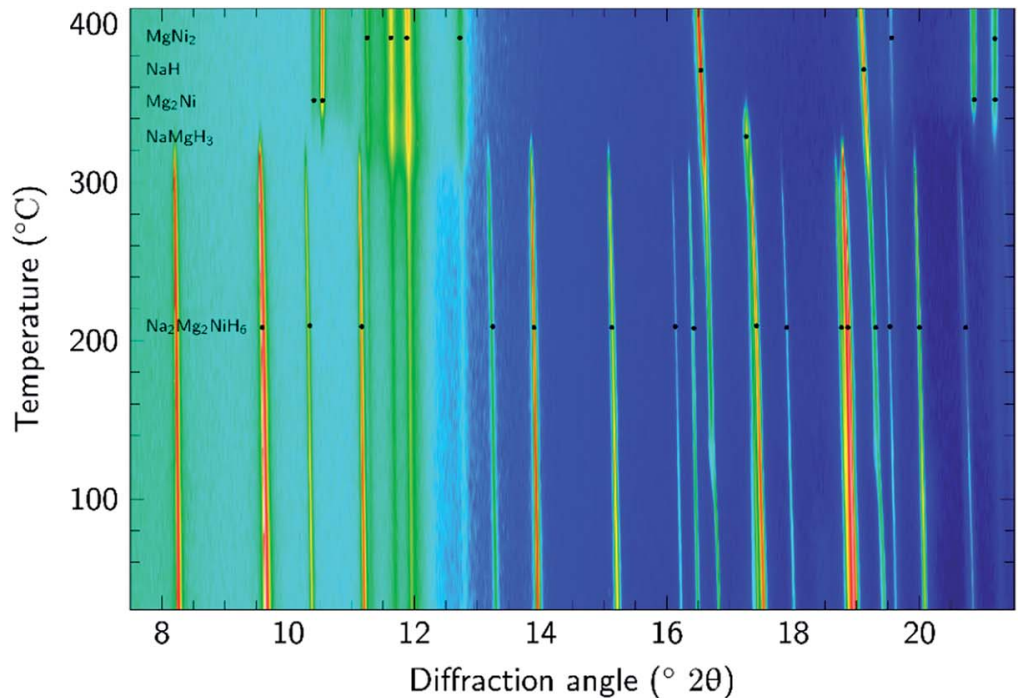

(a)

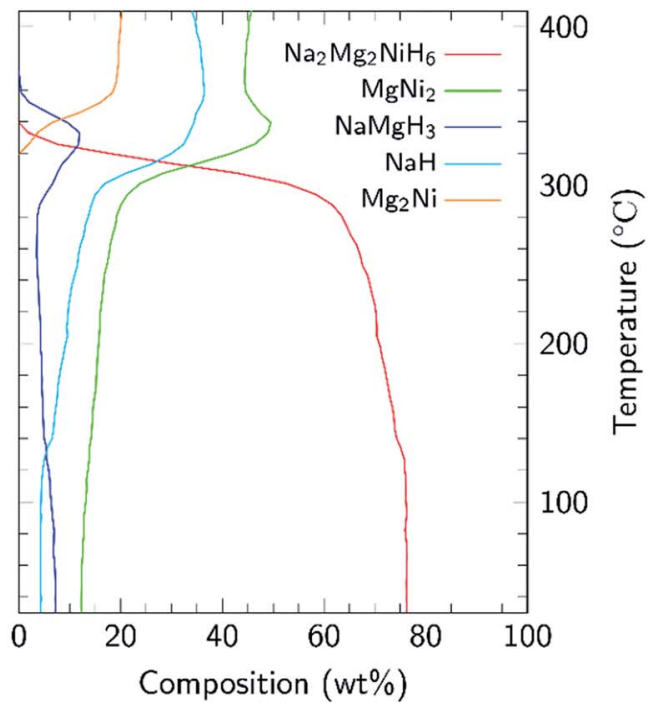

(b)

Fig. 3 (a) Two-dimensional in situ SR-XRD plot for $\mathrm{Na}_{2} \mathrm{Mg}_{2} \mathrm{NiH}_{6}$ and (b) phase composition of $\mathrm{Na}_{2} \mathrm{Mg}_{2} \mathrm{NiH}_{6}$ calculated by Rietveld refinement $\left(\Delta T / \Delta t=5^{\circ} \mathrm{C} \mathrm{min}^{-1}, 1\right.$ bar $\left.\mathrm{H}_{2}, \lambda=0.824890(1) \AA\right)$.

$10 \mathrm{~mol} \% \mathrm{NaOH}$ (w.r.t. $\mathrm{NaH}$ ) is capable of causing up to an $11 \%$ expansion of the $\mathrm{NaH}$ lattice parameters. ${ }^{44} \mathrm{NaOH}$ is not observed in the $\mathrm{Na}_{2} \mathrm{Mg}_{2} \mathrm{NiH}_{6}$ sample at room temperature (Fig. 2), but was detected in the $\mathrm{NaH}$ starting material (3.2 wt\% by quantitative XRD analysis). As $30.1 \mathrm{wt} \% \mathrm{NaH}$ is used as the starting material then at least $0.96 \mathrm{wt} \% \mathrm{NaOH}$ would be expected in the sample, although this is close to the detection limit of X-ray diffraction, depending on crystallinity. Additional $\mathrm{NaOH}$ impurity may also have been introduced during handling of the sample.

Simultaneous DSC-TGA-MS measurements were carried out to determine the decomposition temperature for $\mathrm{Na}_{2} \mathrm{Mg}_{2} \mathrm{NiH}_{6}$ and to characterise the associated hydrogen evolution events, (Fig. 4). Each of the DSC, TGA and MS measurements corroborate the in situ SR-XRD data and indicate that hydrogen release occurs in a two-step process (Fig. 4a) with an initial onset temperature of $\sim 225{ }^{\circ} \mathrm{C}$ determined by DSC (Fig. $4 \mathrm{~b}$ and S3 $\dagger$ ). DSC measurements indicate that all hydrogen release events are endothermic, with the first exhibiting a maximum hydrogen release rate at $278{ }^{\circ} \mathrm{C}$, with a minor shoulder at $300{ }^{\circ} \mathrm{C}$, followed by a major release at $350{ }^{\circ} \mathrm{C}$. These temperatures are lower than those observed by in situ SR-XRD as DSC-TGA-MS is conducted under a stream of Ar, whereas 1 bar $\mathrm{H}_{2}$ backpressure was placed on the sample during in situ SR-XRD experiments.

TGA measurements (Fig. 4c) determine that, by $400{ }^{\circ} \mathrm{C}$, a total of $3 \mathrm{wt} \% \mathrm{H}_{2}$ is released over only two visible mass loss events. This value is $0.8 \mathrm{wt} \%$ lower than the theoretical value of $3.8 \mathrm{wt} \% \mathrm{H}_{2}$ expected for the total decomposition of $\mathrm{Na}_{2} \mathrm{Mg}_{2}$ $\mathrm{NiH}_{6}$. As described above, quantitative XRD analysis of the material had determined a 76.2\% sample purity and as such only $2.9 \mathrm{wt} \% \mathrm{H}_{2}$ is expected to be observed, excluding other hydrogen releasing compounds that may decompose in the same temperature region. The first decomposition step (formation of $\mathrm{NaH}$ and $2 \mathrm{H}_{2}$ ) has an associated mass loss of
$1.5 \mathrm{wt} \%$ between 250 and $315{ }^{\circ} \mathrm{C}$, which is lower than the $2.5 \mathrm{wt} \%$ expected for the decomposition of $\mathrm{Na}_{2} \mathrm{Mg}_{2} \mathrm{NiH}_{6}$ (1.9 wt\% expected accounting for impurities). As seen in Fig. 3b, a small quantity of $\mathrm{NaMgH}_{3}$ is formed during the first stage of decomposition and, as such, would rescind some of the $\mathrm{H}_{2}$ that would be expected to desorb if decomposition were to follow a two-step pathway.

The second mass loss event releases $1.4 \mathrm{wt} \%$ hydrogen between 315 and $383^{\circ} \mathrm{C}$. This quantity is close to the theoretical hydrogen capacity for this step corresponding to the decomposition of 2 equivalents of $\mathrm{NaH}$, although when the purity of the material is considered, only $1.1 \mathrm{wt} \%$ is expected. The increased capacity corresponds with the decomposition of the $\mathrm{NaMgH}_{3}$ formed and any other hydrogen containing impurity phases. In fact, when the in situ SR-XRD data is considered (Fig. 3b), at $315{ }^{\circ} \mathrm{C} \sim 10 \mathrm{wt} \% \mathrm{NaMgH}_{3}$ was determined to be present. Taking the purity of the starting material into consideration, $1.35 \mathrm{wt} \% \mathrm{H}_{2}$ is to be expected to be released. This accounts for the $1.4 \mathrm{wt} \%$ mass loss observed during the second mass loss event in the TGA measurement. This notion is corroborated by the fact that there is no definite separation between the end of the first decomposition stage and the beginning of the second mass loss event $\left(\sim 315^{\circ} \mathrm{C}\right)$ by TGA (Fig. 4c), while a small shoulder is also apparent in both the DSC and MS data at $300{ }^{\circ} \mathrm{C}$ (Fig. 4 and S3 $\dagger$ ).

From the experiments carried out so far, it has been determined that the predominant decomposition pathway of $\mathrm{Na}_{2}$ $\mathrm{Mg}_{2} \mathrm{NiH}_{6}$ is via a two-step process, where $\mathrm{Na}_{2} \mathrm{Mg}_{2} \mathrm{NiH}_{6}$ forms $\mathrm{Na}$ and $\mathrm{Mg}_{2} \mathrm{Ni}$ with $\mathrm{NaMgH}_{3}$ being formed as an intermediate. Further ex situ XRD data were also collected for $\mathrm{Na}_{2} \mathrm{Mg}_{2} \mathrm{NiH}_{6}$ material after it was heated to 260 and $330{ }^{\circ} \mathrm{C}$ in vacuo. These two temperatures were chosen so as to determine the decomposition products at each of the desorption events observed by TGA. A powder sample heated to $260^{\circ} \mathrm{C}$ under vacuum was kept 


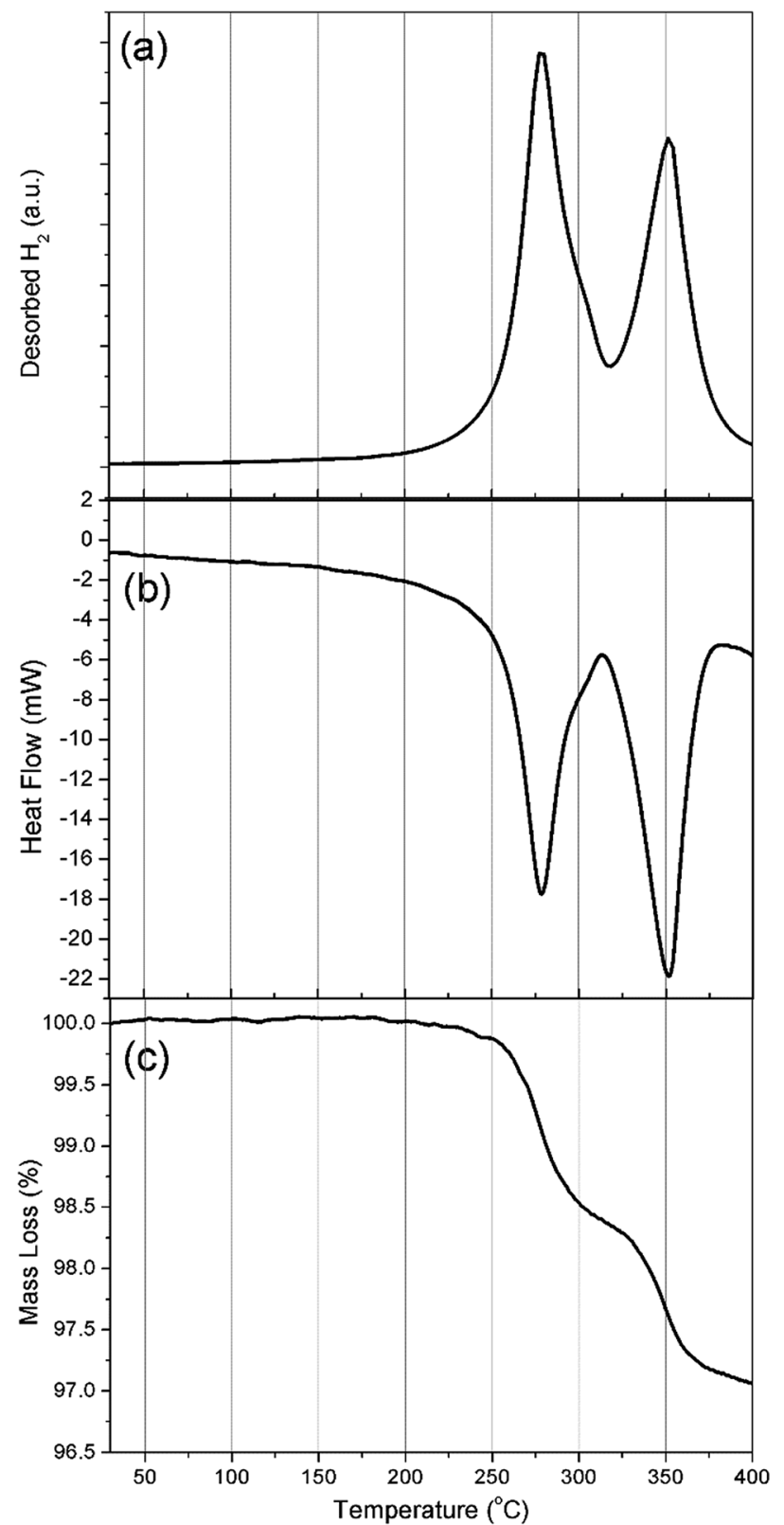

Fig. 4 (a) MS, (b) DSC and (c) TGA analysis of $\mathrm{Na}_{2} \mathrm{Mg}_{2} \mathrm{NiH}_{6} . \Delta T / \Delta t=$ $10{ }^{\circ} \mathrm{C} \mathrm{min}^{-1}$.

isothermal for $2 \mathrm{~h}$ on reaching temperature and, upon analysis by XRD, exhibited peaks for $\mathrm{Na}_{2} \mathrm{Mg}_{2} \mathrm{NiH}_{6}, \mathrm{Mg}_{2} \mathrm{NiH}_{x}(x \leq 0.3)$, $\mathrm{NaH}$ and a small quantity of $\mathrm{MgNi}_{2}$ (Fig. S4 $\dagger$ ). No Bragg peaks for $\mathrm{NaMgH}_{3}$ were observed, which may be due to the ex situ XRD experiments being carried out in vacuo, whereas the in situ SRXRD experiments being carried out under 1 bar $\mathrm{H}_{2}$. This pressure may have allowed for the formation of $\mathrm{NaMgH}_{3}$ which is stable at 1 bar $\mathrm{H}_{2}$ pressure at $382{ }^{\circ} \mathrm{C}$ whereas it will decompose under vacuum conditions. ${ }^{45}$ Further heating of the material to $330{ }^{\circ} \mathrm{C}$, under vacuum, followed by a $12 \mathrm{~h}$ isothermal stage yielded predominantly $\mathrm{Mg}_{2} \mathrm{NiH}_{x}, \mathrm{NaH}$ and a small quantity of $\mathrm{MgNi}_{2} . \mathrm{Mg}_{2} \mathrm{NiH}_{x}$ was not modelled during refinement of the in situ SR-XRD data. This is because $\mathrm{Mg}_{2} \mathrm{NiH}_{x}$ and $\mathrm{Mg}_{2} \mathrm{Ni}$ exist in the same space group $\left(\mathrm{P6}_{2} 22\right)$ and only vary by their lattice parameters. $^{46}$ Due to the inclusion of $\mathrm{H}$ in the lattice, $\mathrm{Mg}_{2} \mathrm{NiH}_{0.29}$ has a unit cell volume of $321.4 \AA^{3}$, whereas $\mathrm{Mg}_{2} \mathrm{Ni}$ has a unit cell volume of $311.0 \AA^{3}$. The slight difference in lattice parameters ensures that it is difficult to differentiate between these species, especially when indexing diffraction data measured at high temperatures (due to thermal lattice expansion). Nevertheless, when the materials are cooled to room temperature, these compounds can be distinguished. The detection of $\mathrm{Mg}_{2} \mathrm{NiH}_{x}(x \leq 0.3)$ is not unexpected as it is commonly seen during studies of the related $\mathrm{Mg}_{2} \mathrm{NiH}_{4} \cdot{ }^{46}$ The $\mathrm{Mg}_{2} \mathrm{NiH}_{x}$ phases observed in the materials heated to 260 and $330{ }^{\circ} \mathrm{C}$ have room temperature unit cell volumes of $318 \AA^{3}$, indicating that the stoichiometry of $\mathrm{H}$ is closer to 0.3 than 0 and that the vestiges of $\mathrm{H}$ are difficult to remove from $\mathrm{Mg}_{2} \mathrm{Ni}$. The presence of this phase accounts for the reduced hydrogen capacity of the material observed during TGA measurements for the first decomposition step. Therefore, the decomposition of $\mathrm{Na}_{2} \mathrm{Mg}_{2} \mathrm{NiH}_{6}$ can be explained as

$$
\begin{gathered}
\mathrm{Na}_{2} \mathrm{Mg}_{2} \mathrm{NiH}_{6} \rightarrow \mathrm{Mg}_{2} \mathrm{NiH}_{x}+2 \mathrm{NaH}+(2-x) \mathrm{H}_{2}(x<0.3) \\
2 \mathrm{NaH} \rightarrow 2 \mathrm{Na}+\mathrm{H}_{2}
\end{gathered}
$$

\section{PCI analysis}

Following the determination of the decomposition temperature of $\mathrm{Na}_{2} \mathrm{Mg}_{2} \mathrm{NiH}_{6}$, PCI measurements were undertaken at five temperatures between 370 and $451{ }^{\circ} \mathrm{C}$ to determine the thermodynamics of the $\mathrm{H}_{2}$ desorption process (Fig. 5). Only the first step of this process (eqn (7)) was measured as to inhibit the decomposition of $\mathrm{NaH}$, which inevitably leads to the distillation of $\mathrm{Na}$ metal to cooler parts of the instrument. ${ }^{47-49}$ In regards to technological application, the formation of $\mathrm{Na}$ metal is undesirable and the thermodynamics of that process are understood. $^{30}$ The pressure of the equilibrium plateaux were measured at $0.6 \mathrm{wt} \%$, which allowed for a van't Hoff plot with a corresponding $R^{2}$ factor of 0.999 . As a result, $\Delta H_{\mathrm{des}}$ and $\Delta S_{\mathrm{des}}$ were determined to be $83 \pm 3 \mathrm{~kJ} \mathrm{~mol}^{-1} \mathrm{H}_{2}$ and $140 \pm 4 \mathrm{~J} \mathrm{~K}^{-1}$ $\mathrm{mol}^{-1} \mathrm{H}_{2}$, respectively. Assuming that $\mathrm{Mg}_{2} \mathrm{Ni}$ has no thermodynamic or kinetic effect on the decomposition of $\mathrm{NaH}$, then the second stage of decomposition (eqn (8)) will have a $\Delta H_{\mathrm{des}}$ and $\Delta S_{\mathrm{des}}$ of $117 \pm 2 \mathrm{~kJ} \mathrm{~mol}^{-1} \mathrm{H}_{2}$ and $167 \mathrm{~J} \mathrm{~K}^{-1} \mathrm{~mol}^{-1} \mathrm{H}_{2}$, respectively, based on literature data. ${ }^{30}$ This gives a total $\Delta H_{\mathrm{des}}$ and $\Delta S_{\text {des }}$ of $283 \pm 6 \mathrm{~kJ} \mathrm{~mol}^{-1}\left(94.33 \pm 3 \mathrm{~kJ} \mathrm{~mol}^{-1} \mathrm{H}_{2}\right)$ and $447 \pm$ $8 \mathrm{~J} \mathrm{~K}^{-1} \mathrm{~mol}^{-1}\left(149 \pm 4 \mathrm{~J} \mathrm{~K}^{-1} \mathrm{~mol}^{-1} \mathrm{H}_{2}\right)$, respectively.

In regards to the analogous compound $\mathrm{MgNiH}_{4}, \mathrm{Na}_{2} \mathrm{Mg}_{2}$ $\mathrm{NiH}_{6}$ is considerably more stable in terms of both enthalpy and entropy. $\mathrm{Mg}_{2} \mathrm{NiH}_{4}$ decomposes to $\mathrm{Mg}_{2} \mathrm{Ni}_{x}$ (eqn (1)) with a $\Delta H_{\text {des }}$ of $63 \mathrm{~kJ} \mathrm{~mol}^{-1} \mathrm{H}_{2}$, while $\Delta S$ is $120 \mathrm{~J} \mathrm{~K}^{-1} \mathrm{~mol}^{-1} \mathrm{H}_{2} \cdot{ }^{13}$ The $\Delta H_{\text {des }}$ of $\mathrm{Na}_{2} \mathrm{Mg}_{2} \mathrm{NiH}_{6}$ to $\mathrm{Mg}_{2} \mathrm{Ni}_{x}$ and $\mathrm{NaH}$ (eqn (7) \& (8)) is $31.33 \mathrm{~kJ} \mathrm{~mol}^{-1}$ larger due to the additional stability achieved by the incorporation of $\mathrm{Na}^{+}$and $\mathrm{H}^{-}$into the compound. ${ }^{50,51}$ This effect has been observed previously in analogous compounds of $\mathrm{Na}_{2}$ $\mathrm{Mg}_{2} \mathrm{FeH}_{8}$ and $\mathrm{Mg}_{2} \mathrm{FeH}_{6}$, which have a total $\Delta H_{\text {des }}$ of 378 and $261 \mathrm{~kJ} \mathrm{~mol}^{-1}$, respectively, or 94.5 and $87 \mathrm{~kJ} \mathrm{~mol}^{-1} \mathrm{H}_{2}$, respectively. ${ }^{50}$ In $\mathrm{Na}_{2} \mathrm{Mg}_{2} \mathrm{FeH}_{8}$, the decomposition to $2 \mathrm{NaH}, 2 \mathrm{Mg}$ and 

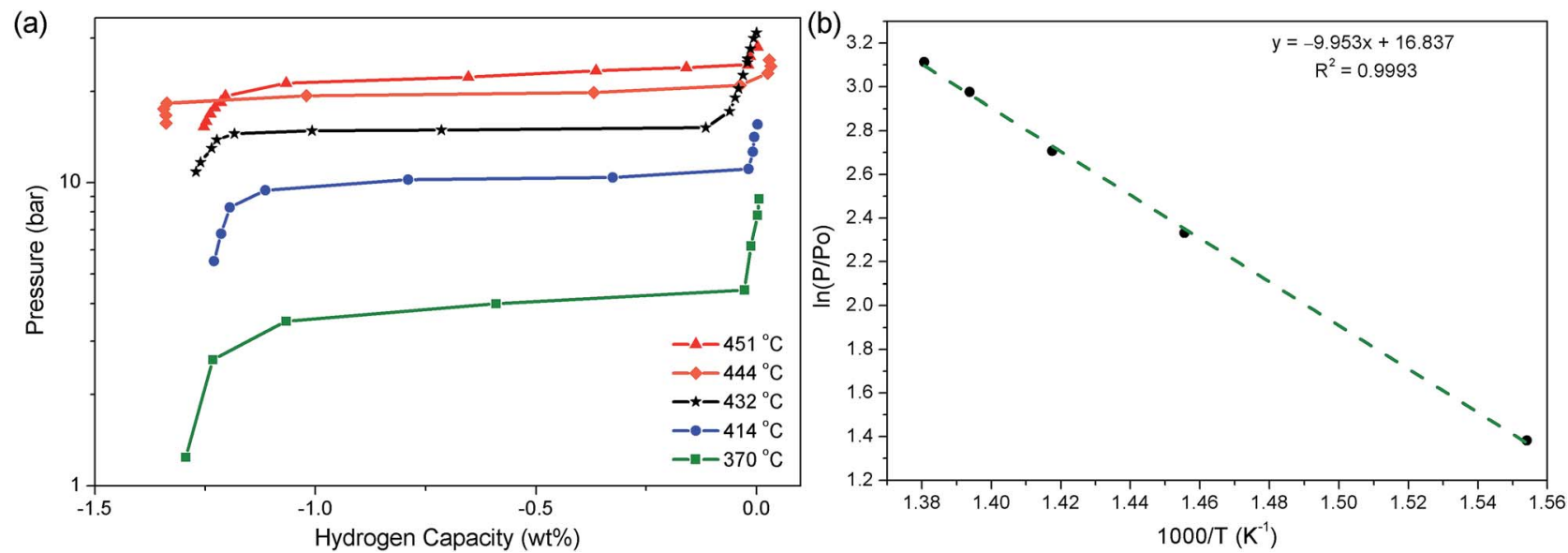

Fig. 5 (a) $\mathrm{PCl}$ analysis of $\mathrm{Na}_{2} \mathrm{Mg}_{2} \mathrm{NiH}_{6}$ at selected temperatures and (b) van't Hoff plot of respective $\mathrm{H}_{2}$ desorption equilibrium pressures.

Fe has a $\Delta H_{\text {des }}$ of $89 \mathrm{~kJ} \mathrm{~mol}^{-1} \mathrm{H}_{2}$, while $\Delta H_{\text {des }}$ of $\mathrm{Mg}_{2} \mathrm{FeH}_{6}$ to $2 \mathrm{Mg}$ and $\mathrm{Fe}$ is $87 \mathrm{~J} \mathrm{~K}^{-1} \mathrm{~mol}^{-1} \mathrm{H}_{2}$. This particular process seems energetically very similar, but the decomposition of $\mathrm{Na}_{2} \mathrm{Mg}_{2}-$ $\mathrm{FeH}_{8}$ to $2 \mathrm{NaH}, 2 \mathrm{Mg}$ and Fe actually proceeds in two steps, via $\mathrm{NaMgH}_{3}$, with the first step having an equilibrium plateau of 100 bar at $380{ }^{\circ} \mathrm{C}\left(\Delta H_{\text {des }}=93 \mathrm{~kJ} \mathrm{~mol}^{-1} \mathrm{H}_{2}\right)$.

\section{Rehydrogenation and cycling experiments}

Rehydrogenation experiments were conducted on material that had been decomposed at $415{ }^{\circ} \mathrm{C}$ with pressure being kept between 1 and 2 bar $\mathrm{H}_{2}$. This was to ensure total decomposition of all $\mathrm{NaMgH}_{3}$ that may be contained in the sample without decomposing NaH. Samples were then subjected to identical conditions as used for initial synthesis but without formation of pellets $\left(60 \mathrm{bar}_{2}, 315{ }^{\circ} \mathrm{C}, 20 \mathrm{~h}\right)$. Quantitative Rietveld refinement of the rehydrided products confirmed a composition of 85.3(6) wt $\% \mathrm{Na}_{2} \mathrm{Mg}_{2} \mathrm{NiH}_{6}, 6.9(4) \mathrm{wt} \% \mathrm{MgNi}_{2}, 2.8(3) \mathrm{wt} \% \mathrm{NaH}$, $1.9(2) \mathrm{wt} \% \mathrm{Ni}$ and only $3.1(3) \mathrm{wt} \% \mathrm{NaMgH}_{3}$ showing that rehydrogenation is achievable.

Due to early reports, ${ }^{\mathbf{2 1}, 22}$ all hydrogenation experiments up to this point were carried out at $\mathrm{H}_{2}$ pressures exceeding 30 bar. After the determination of the thermodynamics of decomposition of the first step of $\mathrm{Na}_{2} \mathrm{Mg}_{2} \mathrm{NiH}_{6}$ (eqn (7)), it was deduced that the equilibrium pressure of sorption should be 0.92 bar $\mathrm{H}_{2}$ at $315{ }^{\circ} \mathrm{C}$. An isothermal PCI absorption experiment was conducted at $315{ }^{\circ} \mathrm{C}$ (Fig. S5 $\dagger$ ) resulting in a capacity of $1.2 \mathrm{wt} \% \mathrm{H}_{2}$ at an equilibrium pressure of 2.1 bar. XRD analysis of the hydrogenation product indicated that it was predominantly $\mathrm{NaMgH}_{3}$ along with some $\mathrm{MgNi}_{2}$ and $\mathrm{NaH}$ (Fig. S6 $†$ ). Given the desorption pathway and PCI measurements, $\mathrm{Na}_{2} \mathrm{Mg}_{2} \mathrm{NiH}_{6}$ should have formed under the temperature and pressure applied. Since $\mathrm{NaMgH}_{3}$ is formed instead, which is reported to be less thermodynamically favourable ${ }^{45}$ this suggests fast kinetics for the formation of $\mathrm{NaMgH}_{3}$ from the decomposition products and slow kinetics for the formation of $\mathrm{Na}_{2} \mathrm{Mg}_{2} \mathrm{NiH}_{6}$. Increasing the applied $\mathrm{H}_{2}$ pressure to the decomposition products at $315{ }^{\circ} \mathrm{C}$ (in this case to 60 bar) increases the $\mathrm{Na}_{2}{ }^{-}$ $\mathrm{Mg}_{2} \mathrm{NiH}_{6}$ formation kinetics enough to allow it to form. ${ }^{52}$
However, further investigations would be required to confirm this. In fact, $\mathrm{NaMgH}_{3}$ appears to be a kinetic sink with the necessity for bonding in two moles of $\mathrm{NaMgH}_{3}$ to be broken in order to form 1 mole of $\mathrm{Na}_{2} \mathrm{Mg}_{2} \mathrm{NiH}_{6}$. Therefore, in order for $\mathrm{Na}_{2} \mathrm{Mg}_{2} \mathrm{NiH}_{6}$ to be preferentially formed over $\mathrm{NaMgH}_{3}$, a significant hydrogen overpressure of $>50$ bar is required to be applied during synthesis.

Hydrogen cycling of $\mathrm{Na}_{2} \mathrm{Mg}_{2} \mathrm{NiH}_{6}$ was conducted 10 times utilising only the first decomposition step (eqn (7), Fig. 6). The first desorption (starting from the pristine state) was carried out by ramping the sample from $315{ }^{\circ} \mathrm{C}$ to $395{ }^{\circ} \mathrm{C}$ under an initial pressure of 0.2 bar $\mathrm{H}_{2}$. These temperatures and pressures were, used to avoid formation of $\mathrm{NaMgH}_{3}$ during absorption. Within $60 \mathrm{~min}$ desorption is almost complete, with $1.36 \mathrm{wt} \% \mathrm{H}_{2}$ being desorbed. A further nine cycles were conducted with isothermal hydrogenation at $315{ }^{\circ} \mathrm{C}$ and dehydrogenation at $395{ }^{\circ} \mathrm{C}$, respectively. Analysis of the Sieverts data indicates that desorption occurs rapidly and is complete within $30 \mathrm{~min}$ with the hydrogen capacity staying consistent within experimental error. Analysis of the material after a final absorption by XRD

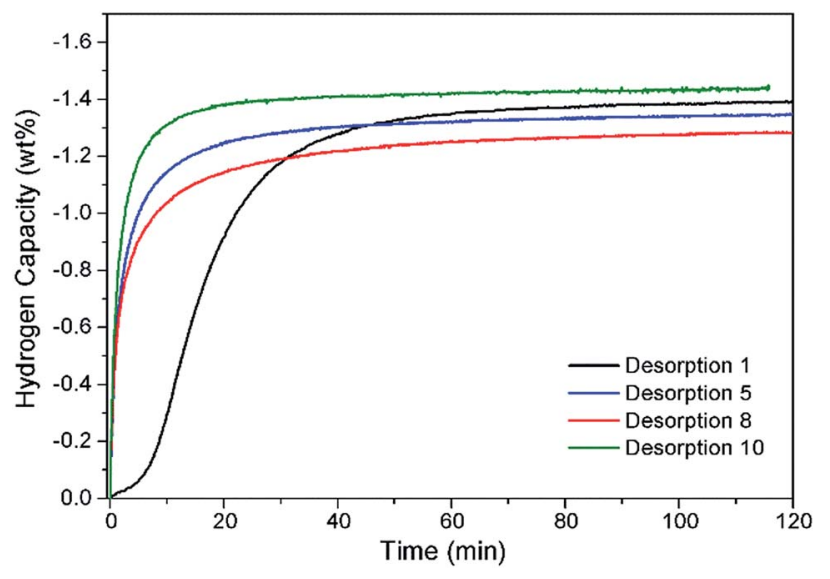

Fig. 6 Hydrogen capacity of $\mathrm{Na}_{2} \mathrm{Mg}_{2} \mathrm{NiH}_{6}$ after ten sorption cycles measured inside a Sieverts apparatus. $T_{\text {des }}=395{ }^{\circ} \mathrm{C}$ and 0.2 bar $\mathrm{H}_{2}$; $T_{\text {abs }}=315^{\circ} \mathrm{C}$ and 60 bar $\mathrm{H}_{2}$. 
Table 2 Properties of selected metal hydrides and calculated operating temperatures between 1 and 150 bar $^{a}$

\begin{tabular}{|c|c|c|c|c|}
\hline Material & $\begin{array}{l}\text { Theoretical } \mathrm{H}_{2} \text { capacity } \\
\text { (wt\%) }\end{array}$ & $\begin{array}{l}\Delta H_{\mathrm{des}} \\
\left(\mathrm{kJ} \mathrm{mol}{ }^{-1} \mathrm{H}_{2}\right)\end{array}$ & $\begin{array}{l}\text { Operating range } \\
\left({ }^{\circ} \mathrm{C}\right)\end{array}$ & $\begin{array}{l}\text { Theoretical thermal } \\
\text { storage capacity }\left(\mathrm{kJ} \mathrm{kg}^{-1}\right)\end{array}$ \\
\hline $\mathrm{Na}_{2} \mathrm{Mg}_{2} \mathrm{NiH}_{6}-1^{\text {st }}$ step & 2.53 & 83 & $318-568$ & 1042 \\
\hline $\mathrm{NaMgH}_{2} \mathrm{~F}$ & 2.95 & 96.8 (ref. 34) & $431-738$ & 1416 \\
\hline $\mathrm{NaMgH}_{3}-1^{\text {st }}$ step & 4.01 & 86.6 (ref. 45 ) & $382-683$ & 1721 \\
\hline $\mathrm{NaH}$ & 4.20 & 116.8 (ref. 30) & $426-659$ & 2434 \\
\hline $\mathrm{Mg}_{2} \mathrm{FeH}_{6}$ & 5.47 & 77 (ref. 54) & $304-564$ & 2090 \\
\hline
\end{tabular}

${ }^{a}$ Pressures noted correspond to calculated fugacities (pressure $=$ fugacity/compressibility of $\mathrm{H}_{2}$ ). ${ }^{b}$ Maximum temperature unachievable due to sintering. ${ }^{55}$

indicates that the material was cycling through $\mathrm{Na}_{2} \mathrm{Mg}_{2} \mathrm{NiH}_{6}$, with the final composition being $\mathrm{Na}_{2} \mathrm{Mg}_{2} \mathrm{NiH}_{6}$ (71.8(5) wt\%), $\mathrm{NaMgH}_{3}(10.9(2) \mathrm{wt} \%), \mathrm{NaH}(5.3(2) \mathrm{wt} \%)$ and $\mathrm{MgNi}_{2}(6.6(3))$, $\mathrm{Mg}_{2} \mathrm{NiH}_{x}$ (5.5(5) wt\%) (Fig. S7 $\dagger$ ). Overall, the rate of desorption and the hydrogen capacity is favourable and shows good viability for application.

Further hydrogen cycling of $\mathrm{Na}_{2} \mathrm{Mg}_{2} \mathrm{NiH}_{6}$ was conducted with desorption measured at $400{ }^{\circ} \mathrm{C}$ and 0.7 bar $\mathrm{H}_{2}$ initial pressure and absorption at $400{ }^{\circ} \mathrm{C}$ and 40 bar $\mathrm{H}_{2}$ pressure (starting from the pristine state). Analysis of the Sieverts data indicates that absorption occurs rapidly and is complete within $3 \mathrm{~min}$ for the first 5 cycles (Fig. S8a $\dagger$ ). The rate of absorption slowly diminishes over the 30 cycles although hydrogenation is still complete within $6 \mathrm{~min}$ after the $30^{\text {th }}$ cycle. The hydrogen capacity of the material also diminishes after the first cycle and over the next nine cycles but appears to stabilise thereafter (Fig. S8b $\dagger$ ). The initial capacity is $1.36 \mathrm{wt} \%$ $\mathrm{H}_{2}$ on the first absorption but is $1.21 \mathrm{wt} \%$ by cycle 30 . XRD analysis of the material after the last absorption showed an identical pattern as observed after carrying out the absorption PCT at $315^{\circ} \mathrm{C}$ at low pressures (Fig. S5 $\dagger$ ). This again indicates that $\mathrm{NaMgH}_{3}$ is acting as a kinetic sink and inhibiting formation of $\mathrm{Na}_{2} \mathrm{Mg}_{2} \mathrm{NiH}_{6}$.

\section{Technological application}

If this material were to be technologically viable for high temperature thermal energy storage (TES) applications, a few criteria must be met. Firstly, a relatively high theoretical thermal storage capacity should be upheld. Unfortunately, due to the high molecular weight of $159 \mathrm{amu}, \mathrm{Na}_{2} \mathrm{Mg}_{2} \mathrm{NiH}_{6}-1^{\text {st }}$ step has a low thermal storage capacity of $1042 \mathrm{~kJ} \mathrm{~kg}^{-1}$ (Table 2). This is much lower than compounds such as $\mathrm{NaBH}_{4}(5709 \mathrm{~kJ}$ $\left.\mathrm{kg}^{-1}\right)$ and $\mathrm{MgH}_{2}\left(2811 \mathrm{~kJ} \mathrm{~kg}^{-1}\right)$ and as such if it were to be implemented, a greater quantity of powder would be required to achieve a similar thermal efficiency. In a similar vein, the theoretical hydrogen capacity of $2.53 \mathrm{wt} \%$ is also comparably lower than the wt\% $\mathrm{H}_{2}$ of $\mathrm{NaBH}_{4}$ (10.67) and $\mathrm{MgH}_{2}$ (7.66), respectively. This would inhibit its use as a hydrogen storage material. On the other hand, if this material was to be paired with a low temperature metal hydride (LTMH) when implemented as a TES (to store the hydrogen during desorption of $\mathrm{H}_{2}$ during the day), less LTMH would be required as less $\mathrm{H}_{2}$ needs to be stored. ${ }^{\mathbf{8 , 3 4}}$

With a $\Delta H_{\text {des }}$ of $83 \mathrm{~kJ} \mathrm{~mol}^{-1}, \mathrm{Na}_{2} \mathrm{Mg}_{2} \mathrm{NiH}_{6}$ would have an operating temperature of $318-568{ }^{\circ} \mathrm{C}$ within a pressure range of 1 and 150 bar. This is in the operating temperature similar to $\mathrm{Mg}_{2} \mathrm{FeH}_{6}$, which has already been investigated as a thermal energy storage material on a scale of $211 \mathrm{~g}$ and has been shown to cycle at least 23 times. ${ }^{9}$ The present study has shown that $\mathrm{Na}_{2} \mathrm{Mg}_{2} \mathrm{NiH}_{6}$ is capable of cycling at least 10 times with full formation of $\mathrm{Na}_{2} \mathrm{Mg}_{2} \mathrm{NiH}_{6}$ at $315{ }^{\circ} \mathrm{C}\left(1.35 \mathrm{wt} \% \mathrm{H}_{2}\right)$. Although the pressure and temperature must be controlled during absorption to prevent formation of $\mathrm{NaMgH}_{3}$. The use of a gas booster to store the desorbed hydrogen to maximise volumetric storage will enable full desorption and provide higher gas pressures for absorption. At higher temperatures the material can be cycled at least 30 times through formation of $\mathrm{NaMgH}_{3}$ with a hydrogen capacity of $1.2 \mathrm{wt} \% \mathrm{H}_{2}$, although despite the fast kinetics and cyclability this material would contain too much dead weight.

Despite its promise, $\mathrm{Na}_{2} \mathrm{Mg}_{2} \mathrm{NiH}_{6}$ is unlikely to find technological application due to its material cost. Ni metal is $\sim \$ 11$ per kg, ${ }^{56}$ leading to $\mathrm{Na}_{2} \mathrm{Mg}_{2} \mathrm{NiH}_{6}$ costing $\sim \$ 21$ per $\mathrm{kg}$, which equates to $72 \mathrm{US} / \mathrm{kWh}_{\mathrm{th}}$. However, there may be alternative applications. For instance, the parent compound, $\mathrm{Mg}_{2} \mathrm{NiH}_{4}$, has been shown to form an electrochromic mirror electrode, or switchable mirror, when formed as a thin film. ${ }^{4}$ This is one aspect of $\mathrm{Na}_{2} \mathrm{Mg}_{2} \mathrm{NiH}_{6}$ that can be further explored. In addition, $\mathrm{Mg}_{2} \mathrm{NiH}_{4}$ has also been shown to be an efficient material to form Ni nanoparticles when hydrolysed. ${ }^{57}$

\section{Conclusions}

The synthesis, thermodynamics and reversible hydrogenation of $\mathrm{Na}_{2} \mathrm{Mg}_{2} \mathrm{NiH}_{6}$ has been studied in detail to determine its feasibility for technological application as a high temperature hydrogen storage material or as a thermal energy storage material. The incorporation of quasi-isolated $\mathrm{H}^{-}$into this class of complex transition metal hydrides has allowed for increased variety of coordination by cations and increased thermal stability. The original synthesis procedure of $\mathrm{Na}_{2} \mathrm{Mg}_{2} \mathrm{NiH}_{6}$ involved a four-step method with the requirement of two mixing stages and two annealing stages. This study reports that only 
one mixing and one annealing stage is required, which results in a reduction of synthesis time by half.

The decomposition pathway of $\mathrm{Na}_{2} \mathrm{Mg}_{2} \mathrm{NiH}_{6}$ has been studied for the first time by in situ SR-XRD and DSC-TGA-MS. $\mathrm{Na}_{2} \mathrm{Mg}_{2} \mathrm{NiH}_{6}$ is observed to commence hydrogen desorption at $225{ }^{\circ} \mathrm{C}$ with two decomposition steps, with maximum $\mathrm{H}_{2}$ desorption rates at $278{ }^{\circ} \mathrm{C}$ and $350{ }^{\circ} \mathrm{C}$. The total hydrogen capacity was determined to be $2.9 \mathrm{wt} \%$ when heated up to $400{ }^{\circ} \mathrm{C}$ if all hydrogen is desorbed (theoretical $3.8 \mathrm{wt} \% \mathrm{H}_{2}$ ). The first step of decomposition is the formation of $\mathrm{Mg}_{2} \mathrm{NiH}_{x}(x<$ 0.3 ), and $\mathrm{NaH}$. The second step is the decomposition of $\mathrm{NaH}$. The theoretical hydrogen capacity of $3.8 \mathrm{wt} \%$ is not achieved during desorption due to the formation of unreactive $\mathrm{MgNi}_{2}$ during synthesis. PCI analysis of $\mathrm{Na}_{2} \mathrm{Mg}_{2} \mathrm{NiH}_{6}$ has determined the thermodynamics of decomposition for the first step to have a $\Delta H_{\text {des }}$ and $\Delta S_{\text {des }}$ of $83 \pm 3 \mathrm{~kJ} \mathrm{~mol}^{-1} \mathrm{H}_{2}$ and $140 \pm 4 \mathrm{~J} \mathrm{~K}^{-1} \mathrm{~mol}^{-1}$ $\mathrm{H}_{2}$, respectively. Thermodynamics for the complete decomposition are found to be $\Delta H_{\mathrm{des}}$ and $\Delta S_{\mathrm{des}}$ of $283 \pm 6 \mathrm{~kJ} \mathrm{~mol}^{-1}(94 \pm$ $\left.3 \mathrm{~kJ} \mathrm{~mol}^{-1} \mathrm{H}_{2}\right)$ and $447 \pm 8 \mathrm{~J} \mathrm{~K}^{-1} \mathrm{~mol}^{-1}\left(149 \pm 4 \mathrm{~J} \mathrm{~K}^{-1} \mathrm{~mol}^{-1} \mathrm{H}_{2}\right)$, respectively.

Hydrogen cycling of the first step of decomposition has been demonstrated over 10 cycles with no significant reduction in hydrogen capacity. Each cycle desorbed $\sim 1.35 \mathrm{wt} \% \mathrm{H}_{2}$ in under $20 \mathrm{~min}$. It was imperative to apply moderately high pressure to achieve hydrogenation of $\mathrm{Na}_{2} \mathrm{Mg}_{2} \mathrm{NiH}_{6}$ and to avoid formation of $\mathrm{NaMgH}_{3}$.

Technological implementation of $\mathrm{Na}_{2} \mathrm{Mg}_{2} \mathrm{NiH}_{6}$ as a high temperature hydride or thermal energy storage material may be hindered by the relatively high cost of the material of $\$ 21$ per $\mathrm{kg}$, which equates to $72 \mathrm{US} \$ / \mathrm{kWh}_{\text {th }}$. This expense is attributed to the high cost of Ni. Nevertheless, this material would have an operating temperature of $318-568{ }^{\circ} \mathrm{C}$ between a pressure range of 1 and 150 bar $\mathrm{H}_{2}$ with impressive cyclability.

With regards to the use of CTMHs as TES materials, it has been shown that the inclusion of sodium, or other metals with high vapour pressures, will inhibit the operating temperatures of the system in order to avoid evaporation and capacity loss. Despite this, a variety of CTMHs have been identified as possible TES materials, ${ }^{\mathbf{4 , 8 , 1 0}}$ although, to date, their thermal properties have not been fully explored.

\section{Conflicts of interest}

There are no conflicts to declare.

\section{Acknowledgements}

CEB, DAS and MP acknowledges the financial support of the Australian Research Council (ARC) for ARC Linkage grant LP120101848, LP150100730 and ARC LIEF grants LE0989180 and LE0775551, which enabled the XRD and gas sorption studies to be done. DAS acknowledges the financial support of a Curtin University Postdoctoral Research Fellowship. MP acknowledges the financial support of the ARC Future Fellowship grant FT160100303. The authors also acknowledge funding from the Australian Synchrotron (ANSTO), which enabled the research at the powder diffraction beamline to be undertaken.

\section{Notes and references}

1 K. Møller, D. Sheppard, D. Ravnsbæk, C. E. Buckley, E. Akiba, H.-W. Li and T. Jensen, Energies, 2017, 10, 1645.

2 C. Frommen, M. H. Sørby, M. Heere, T. D. Humphries, J. E. Olsen and B. C. Hauback, Energies, 2017, 10, 2115.

3 M. B. Ley, L. H. Jepsen, Y.-S. Lee, Y. W. Cho, J. M. Bellosta von Colbe, M. Dornheim, M. Rokni, J. O. Jensen, M. Sloth, Y. Filinchuk, J. E. Jørgensen, F. Besenbacher and T. R. Jensen, Mater. Today, 2014, 17, 122-128.

4 T. D. Humphries, D. A. Sheppard and C. E. Buckley, Coord. Chem. Rev., 2017, 342, 19-33.

5 S. Takagi, Y. Iijima, T. Sato, H. Saitoh, K. Ikeda, T. Otomo, K. Miwa, T. Ikeshoji, K. Aoki and S. Orimo, Angew. Chem., Int. Ed., 2015, 54, 5650-5653.

6 S. Takagi and S. Orimo, Scr. Mater., 2015, 109, 1-5.

7 D. A. Sheppard, T. D. Humphries and C. E. Buckley, Appl. Phys. A, 2016, 122, 406.

8 D. A. Sheppard, M. Paskevicius, T. D. Humphries, M. Felderhoff, G. Capurso, J. Bellosta von Colbe, M. Dornheim, T. Klassen, P. A. Ward, J. A. Teprovich, C. Corgnale, R. Zidan, D. M. Grant and C. E. Buckley, Appl. Phys. A, 2016, 122, 395.

9 R. Urbanczyk, M. Meggouh, R. Moury, K. Peinecke, S. Peil and M. Felderhoff, Appl. Phys. A, 2016, 122, 315.

10 K. M. Nicholson and D. S. Sholl, Inorg. Chem., 2014, 53, 11833-11848.

11 K. Yvon, Chimia, 1998, 52, 613-619.

12 K. Yvon and G. Renaudin, Hydrides: Solid State Transition Metal Complexes, John Wiley \& Sons, Ltd, 2006.

13 J. J. Reilly and R. H. Wiswall, Inorg. Chem., 1968, 7, 22542256.

14 T. D. Humphries, S. Takagi, G. Li, M. Matsuo, T. Sato, M. H. Sørby, S. Deledda, B. C. Hauback and S. Orimo, J. Alloys Compd., 2015, 645, S347-S352.

15 S. F. Parker, Coord. Chem. Rev., 2010, 254, 215-234.

16 A. Züttel, M. Hirscher, B. Panella, K. Yvon, S.-i. Orimo, B. Bogdanović, M. Felderhoff, F. Schüth, A. Borgschulte, S. Goetze, S. Suda and M. T. Kelly, Hydrogen as a Future Energy Carrier, Wiley-VCH Verlag GmbH \& Co. KGaA, 2008.

17 P. Zolliker, K. Yvon, J. D. Jorgensen and F. J. Rotella, Inorg. Chem., 1986, 25, 3590-3593.

18 Z. Gavra, M. H. Mintz, G. Kimmel and Z. Hadari, Inorg. Chem., 1979, 18, 3595-3597.

19 B. Huang and K. Yvon, J. Alloys Compd., 1992, 178, 173-179. 20 B. Huang, K. Yvon and P. Fischer, J. Alloys Compd., 1994, 204, 5-8.

21 K. Kadir and D. Noréus, Inorg. Chem., 2007, 46, 2220-2223.

22 M. Orlova, J.-P. Rapin and K. Yvon, Inorg. Chem., 2009, 48, 5052-5054.

23 M. Di Chio, A. Ziggiotti and M. Baricco, Intermetallics, 2008, 16, 102-106.

24 G. Renaudin, L. Guenee and K. Yvon, J. Alloys Compd., 2003, 350, 145-150.

25 J.-N. Chotard, Y. Filinchuk, B. Revaz and K. Yvon, Angew. Chem., 2006, 118, 7934-7937. 
26 T. D. Humphries, D. A. Sheppard and C. E. Buckley, Chem. Commun., 2015, 51, 11248-11251.

27 M. Paskevicius, D. A. Sheppard and C. E. Buckley, J. Am. Chem. Soc., 2010, 132, 5077-5083.

28 H. Yukawa, M. Takagi and M. Morinaga, Bull. Mater. Sci., 1999, 22, 885-890.

29 J. F. Herbst, J. Alloys Compd., 2002, 337, 99-107.

30 F. D. Manchester and A. San-Martin, Phase Diagrams of Binary Hydrogen Alloys, ASM International, Ohio, 2000.

31 K. S. Wallwork, B. J. Kennedy and D. Wang, Synchrotron Radiation Instrumentation: Ninth International Conference on Synchrotron Radiation Instrumentation, 2007, vol. 879, pp. 879-882.

32 B. Schmitt, C. Brönnimann, E. Eikenberry, F. Gozzo, C. Hörmann, R. Horisberger and B. Patterson, Nucl. Instrum. Methods Phys. Res., Sect. A, 2003, 501, 267-272.

33 R. A. Young and R. A. Young, The Rietveld Method, Oxford University Press, 1995.

34 D. A. Sheppard, C. Corgnale, B. Hardy, T. Motyka, R. Zidan, M. Paskevicius and C. E. Buckley, RSC Adv., 2014, 4, 2655226562.

35 H. Blomqvist and D. Noréus, J. Appl. Phys., 2002, 91, 51415148.

36 J. P. Darnaudery, M. Pezat, B. Darriet and P. Hagenmuller, Mater. Res. Bull., 1981, 16, 1237-1244.

37 G. N. Garcia, J. P. Abriata, J. O. Sofo and G. García, Phys. Rev. $B, \mathbf{1 9 9 9 , ~ 5 9 , ~ 1 1 7 4 6 - 1 1 7 5 4 . ~}$

38 R. Martinez-Coronado, M. Retuerto and J. A. Alonso, Int. J. Hydrogen Energy, 2012, 37, 4188-4193.

39 W. R. Myers, L. W. W. Wang, T. J. Richardson and M. D. Rubin, J. Appl. Phys., 2002, 91, 4879-4885.

40 S. F. Parker, K. P. J. Williams, T. Smith, M. Bortz, B. Bertheville and K. Yvon, Phys. Chem. Chem. Phys., 2002, 4, 1732-1737.

41 Y. Pivak, V. Palmisano, H. Schreuders and B. Dam, J. Mater. Chem. A, 2013, 1, 10972-10978.
42 M. Polanski, T. K. Nielsen, I. Kunce, M. Norek, T. Płociński, L. R. Jaroszewicz, C. Gundlach, T. R. Jensen and J. Bystrzycki, Int. J. Hydrogen Energy, 2013, 38, 4003-4010.

43 P. Zolliker, K. Yvon and C. Baerlocher, J. Less-Common Met., 1986, 115, 65-78.

44 E. G. Sorte, E. H. Majzoub, T. Ellis-Caleo, B. A. Hammann, G. Wang, D. Zhao, R. C. Bowman and M. S. Conradi, J. Phys. Chem. C, 2013, 117, 23575-23581.

45 D. A. Sheppard, M. Paskevicius and C. E. Buckley, Chem. Mater., 2011, 23, 4298-4300.

46 D. Noreus and P. E. Werner, Acta Chem. Scand., Ser. A, 1982, 36, 847-851.

47 D. M. Banus, J. J. McSharry and E. A. Sullivan, J. Am. Chem. Soc., 1955, 77, 2007-2010.

48 W. Klostermeier and E. U. Franck, Ber. Bunsen-Ges. Phys. Chem., 1982, 86, 606-612.

49 T. D. Humphries, D. A. Sheppard, M. R. Rowles, M. V. Sofianos and C. E. Buckley, J. Mater. Chem. A, 2016, 4, 12170-12178.

50 T. D. Humphries, M. Matsuo, G. Li and S.-i. Orimo, Phys. Chem. Chem. Phys., 2015, 17, 8276-8282.

51 S. Takagi, T. D. Humphries, K. Miwa and S. Orimo, Appl. Phys. Lett., 2014, 104, 203901.

52 T. Ichikawa, K. Tokoyoda, H. Leng and H. Fujii, J. Alloys Compd., 2005, 400, 245-248.

53 Outokumpu, HSC Chemistry, 6.1, 2006.

54 A. Reiser, B. Bogdanovic and K. Schlichte, Int. J. Hydrogen Energy, 2000, 25, 425-430.

55 B. Bogdanović, H. Hofmann, A. Neuy, A. Reiser, K. Schlichte, B. Spliethoff and S. Wessel, J. Alloys Compd., 1999, 292, 5771.

56 Metal Prices.com, http://www.metalprices.com/metal/ magnesium/magnesium-99-9-usa, accessed 04 December 2016.

57 H. Wang, L. Han, H. Hu and D. O. Northwood, J. Alloys Compd., 2009, 470, 539-543. 